ISSN 1392-3196 / e-ISSN 2335-8947

Zemdirbyste-Agriculture, vol. 101, No. 3 (2014), p. 327-332

DOI 10.13080/z-a.2014.101.042

\title{
Predicting apple tree (Malus $\times$ domestica Borkh.) canopy architecture: phytohormone balance in juvenile hybrids
}

\author{
Vidmantas BENDOKAS ${ }^{1}$, Dalia GELVONAUSKIENE ${ }^{1}$, Bronislovas GELVONAUSKIS ${ }^{2}$, \\ Tadeusas SIKSNIANAS ${ }^{1}$, Vidmantas STANYS ${ }^{1,3}$ \\ ${ }^{1}$ Institute of Horticulture, Lithuanian Research Centre for Agriculture and Forestry \\ Kauno 30, Babtai, Kaunas distr., Lithuania \\ E-mail: v.bendokas@1sdi.lt \\ ${ }^{2}$ Plant Gene Bank \\ Stoties 2, Akademija, Kèdainiai distr., Lithuania \\ ${ }^{3}$ Aleksandras Stulginskis University \\ Studentų 11, Akademija, Kaunas distr., Lithuania
}

\begin{abstract}
Apple tree (Malus $\times$ domestica Borkh.) is one of the most widespread and economically important fruit trees. Productivity and economic effect of apple orchards depend on many strongly related factors, one of them being tree canopy architecture, which determines fruit bearing and demand for pruning. Main apple canopy architecture topics are related to application of growth regulators, fertilizers, studies of shoot development and pruning, and environmental influence while physiologic aspects are studied less. Phytohormones play a major role in controlling many physiological processes of plant growth and development. Different amounts of phytohormones are found in the shoots of apple trees depending on their canopy architecture. However, information about phytohormones and their ratio in juvenile orchard plants is insufficient. Our goal was to identify phytohormones related to apple canopy architecture and to evaluate their usage as biochemical markers in predicting future canopy ideotype of apple seedlings in the first year of growth.

It was established that large amount of auxin and high auxin to zeatin ratio are specific to columnar apple trees and they can be used as biochemical markers in juvenile phase. These amounts and ratios are similar in juvenile and cropping columnar apple trees, so phytohormone amount and ratio is independent of tree development stage. It is possible to select columnar apple hybrids in the first year of growth, thus reducing breeding expenses.
\end{abstract}

Key words: canopy architecture, ideotype, juvenile, Malus, phytohormone balance.

\section{Introduction}

Canopy architecture of a horticultural plant is a biological trait, which determines fruit bearing and demand for pruning. Thus it is important to develop new orchard construction and maintenance concepts, which exploit biological potencies of a plant, reduce maintenance expenses and increases economic value. The orchard must be planted in the way, that every fruit tree attained as much light as possible (Jackson, 1980) for fruit ripening and colouring (Wünsche, Lakso, 2000). In order to optimize orchard management system, profound knowledge on tree growth, branching, flowering and other important processes, which depend on canopy architecture of a seedling, is needed (Costes et al., 2006). Training the seedling with minimal pruning and paying special attention to natural plant canopy architecture ideotype may increase productivity of a tree (Lespinasse, 1992; Lauri et al., 2008). Creation of new varieties with compact and undemanding for management canopy architecture is very important in apple breeding (Kenis, Keulemans, 2007).
Bernhard divided apple trees according to their canopy into groups from columnar to weeping estimating direction of main shoots and their fruiting type (Bernhard, 1961). Spur type bearing was defined as fruit bearing on spurs, which are branched out from an older shoot, in opposition are tip-bearing cultivars; they bear fruits on tips of longer shoots. One more parameter - the position of the scaffold branches along the trunk from basitonic to acrotonic, was included later (Lespinasse, Delort, 1986; Lauri et al., 1995). Only typical columnar cultivars were included into the first group by Lespinasse and all spur ideotype cultivars into the second group. Only spur type apple cultivars belong to these groups (Lespinasse, 1992). As a result, commercial apple cultivars may be classified into four main ideotypes according to their vegetative growth and bearing: I - columnar apples, II - spur type apple trees, III - standard ideotypes and IV - weeping cultivars.

The main apple canopy architecture topics are related to application of growth regulators, fertilizers, 
studies of shoot development and pruning, and environmental influence. Genetic and physiologic aspects are studied less. Search for molecular, biochemical or morphological markers linked with desired traits is important for modern breeding, and their usage accelerates breeding process (Kenis, Keulemans, 2007; Lammerts van Bueren et al., 2010; Bendokas et al., 2012).

Phytohormones play a major role in controlling many physiological processes of plant growth and development - tropism (Esmon et al., 2005), plant architecture (Ongaro, Leyser, 2007; Umehara et al., 2008), responses to biotic and abiotic stresses (Spoel, Dong, 2008; Chan, 2012), development of flowers and embryo (Aloni et al., 2006). They regulate division, expansion and differentiation of cells thus determining plant morphological traits (Opik, Rolfe, 2005). Apical dominance is important for the formation of plant canopy, and is known to be driven by auxin (Aloni et al., 2006). Apical dominance is the control exerted by the shoot apex over the outgrowth of the lateral buds (Cline, Oh, 2006). This control determines lateral shoot development and herewith plant canopy architecture. Apical dominance is driven by inhibition of lateral bud development by auxin, while cytokinin promotes growth of axillary buds, and these hormones influence each other (Leyser, 2009). Auxin is mainly produced in young leaves and in the shoot apex and is transported basipetally down the stem (Peer et al., 2011), and induces axillary buds to enter dormancy. Direct application of cytokinin to axillary buds releases them from dormancy, so its action is antagonistic to auxin (Wickson, Thimann, 1958; Shimizu-Sato et al., 2009). Action of phytohormones in apical dominance is well established in common experimental plants pea, Arabidopsis and rice (Umehara et al., 2008), while orchard plants are studied less. It was shown, that different amounts of phytohormones are found in the shoots and leaves of apple trees depending on their canopy architecture (Watanabe et al., 2008; Bendokas, Stanys, 2009). However, information about phytohormones and their ratio in orchard plants is insufficient and mainly based on studies of mature trees. Data on phytohormone balance in juvenile apple trees, and relation to their canopy architecture is lacking.

The aim of the research was to establish phytohormones regulating apple canopy architecture and to evaluate their usage as biochemical markers in predicting future canopy ideotype of apple seedlings in the first year of growth.

\section{Materials and methods}

The study was carried out at the Lithuanian Research Centre for Agriculture and Forestry, Institute of Horticulture in 2007-2011. Crosses were performed in the middle of May, 2007. Parental cultivars and clones were selected according to their canopy architecture. Columnar ideotype CoB-0968 (ㅇ) and Co17-39-52 (ठ) clones, standard ideotype 'Aldas' (q), 'Orlovim' (ठ)

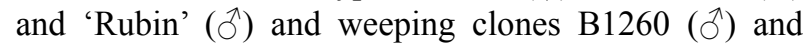
B1267 (ㅇ) were top-crossed (Bendokas et al., 2012).
Many parental plants were selected in order to eliminate the influence of genotype on the phytohormone level in apple leaves and to highlight links of canopy architecture with phytohormone amount. In each cross combination, 500-600 flowers were emasculated, pollinated, and bagged. Seeds were stratified in a moist peat with gravel substrate at $4^{\circ} \mathrm{C}$ until the start of germination. Seedlings were transplanted at five-leaf stage into 3 litre pots and grown unpruned in a plastic greenhouse. Seedling number ranged from 38 to 218 in families. Thirty hybrids from columnar $\times$ weeping, columnar $\times$ standard, weeping $\times$ standard combinations were randomly selected for further phytohormone analysis. Canopy architecture of each hybrid was evaluated at the end of the third year of growth in the greenhouse.

Phytohormones were extracted from hybrid leaves. Fully developed fifth leaves from top were collected from every seedling grown in a greenhouse for three months. Extraction was carried out according to modified Wang method (Wang et al., 2003). $1 \mathrm{~g}$ of fresh leaves was frozen and ground in liquid nitrogen and extracted in $10 \mathrm{~mL}$ of isopropanol for 24 hours at $4^{\circ} \mathrm{C}$. The supernatant was centrifuged at $2500 \times \mathrm{g}$ for $5 \mathrm{~min}$ and residues were re-extracted with $2 \mathrm{~mL}$ of isopropanol. All the supernatants were combined and reduced to aqueous phase in the rotary evaporator; 0.5 $\mathrm{mL}$ of $0.1 \mathrm{M}$ imidazole buffer $(\mathrm{pH} 8.0)$ was added and diluted to $20 \mathrm{~mL}$ with bidistilled water. Phytohormones were purified using $\mathrm{NH}_{2}$ - solid-phase extraction (SPE) columns (Supelco) and concentrated to $0.5 \mathrm{~mL}$ using vacuum concentrator 5301 (Eppendorf AG, Germany).

Phytohormones were analyzed using highperformance liquid chromatography (HPLC). Samples were resolved on a reversed phase $\mathrm{C} 18$ column (Eclipse XDB C18, $4.6 \times 150 \mathrm{~mm}$, Agilent Technologies Inc., USA); Agilent 1200 HPLC system (Agilent Technologies Inc.) with a diode array detector was used. Binary solvent gradient (A 50\% methanol, B 50\% methanol $1.2 \%$ acetic acid) elution was used as follows - initial conditions $50 \%$ B, $3 \mathrm{~min} 50 \%, 7 \mathrm{~min} 60 \%$, $8 \mathrm{~min} 50 \%$ and $10 \mathrm{~min} 50 \%$. Cytokinin - zeatin (Z), gibberellin - gibberellic acid $3\left(\mathrm{GA}_{3}\right)$ and auxin - indole-3-acetic acid (IAA) were detected at the wavelength of $254 \mathrm{~nm}$, while abscisic acid (ABA) at $280 \mathrm{~nm}$. IAA, Z, GA (Duchefa, Netherlands) and ABA (Alfa Aesar GmbH, Germany) standards for identification and quantification of phytohormones were used.

The phytohormone measurements were performed in three replications, data were evaluated statistically using analysis of variance method, Fisher's LSD test at the confidence level $P=0.05$ (Tarakanovas, Raudonius, 2003).

\section{Results and discussion}

Significant differences in phytohormone amount depending on cross combination were established. Higher auxin (IAA) concentration was identified in seedlings from cross combination columnar $\times$ standard, although seedlings from weeping $\times$ standard and columnar $\times$ 
weeping families had similar IAA amount (Table 1). However, significant difference in IAA concentration was identified between seedlings from cross combinations columnar $\times$ standard and weeping $\times$ standard only.

Table 1. Average phytohormone amount in the leaves of hybrid families, according to their parental plant canopy architecture

\begin{tabular}{ccccc}
\hline $\begin{array}{c}\text { Crossing } \\
\text { combination }\end{array}$ & IAA & $\mathrm{Z}$ & $\mathrm{GA}_{3}$ & $\mathrm{ABA}$ \\
\hline Columnar $\times$ & $5.60 \mathrm{ab}$ & $20.3 \mathrm{a}$ & $140.7 \mathrm{~b}$ & $1.25 \mathrm{a}$ \\
weeping & \pm 0.64 & \pm 0.34 & \pm 13.6 & \pm 0.15 \\
& & & \\
Columnar $\times$ & $5.98 \mathrm{~b}$ & $3.80 \mathrm{~b}$ & $87.4 \mathrm{a}$ & $1.97 \mathrm{~b}$ \\
standard & \pm 0.51 & \pm 0.55 & \pm 12.14 & \pm 0.39 \\
Weeping $\times$ & $5.14 \mathrm{a}$ & $3.75 \mathrm{~b}$ & $119.9 \mathrm{~b}$ & $0.79 \mathrm{a}$ \\
standard & \pm 0.53 & \pm 0.48 & \pm 13.50 & \pm 0.15 \\
\hline
\end{tabular}

Note. IAA - indole-3-acetic acid, Z - zeatin, $\mathrm{GA}_{3}$ - gibberellic acid 3, ABA - abscisic acid; means marked by the same letter do not differ significantly (significance at 0.05 level of probability according to Fisher's LSD test) (mean $\pm \mathrm{SE}, \mathrm{n}=30$ ).

Higher $\mathrm{Z}$ amount was established in the hybrids from families with a standard canopy parent and higher $\mathrm{GA}_{3}$ amount was found in the hybrids from families of weeping apple trees as parents (Table 1). Larger ABA quantity was established in the hybrids from the columnar $\times$ standard family. However, plant development also depends on phytohormone ratio, but not on the absolute quantity only (Gray, 2004; Tworkoski et al., 2006; Ongaro, Leyser, 2007). Higher IAA:Z ratio was established in the hybrids from columnar $\times$ weeping family, this family segregated from other families (Table 2). However, IAA: $Z$ ratio in hybrid family derived from columnar $\times$ weeping cross was lower and similar to that of the hybrids from weeping $\times$ standard cross. It is probable that this similarity emerged as parental apple trees with standard canopy architecture had lower $\mathrm{Z}$ amount than trees with columnar or weeping habitat (Bendokas, Stanys, 2009). Hybrids from families with weeping parents were distinguished by higher $\mathrm{GA}_{3}$ :ABA and $\mathrm{GA}_{3}$ :IAA ratios (Table 2), similar trend for $\mathrm{GA}_{3}$ :ABA ratio was observed in parental weeping plants, while $\mathrm{GA}_{3}$ :IAA ratio in parental weeping plants was different (Bendokas, Stanys, 2009). These data were collected from all plants in a hybrid family regardless of seedling phenotype, because it could not be identified in early stage of hybrid development. Therefore definite conclusions about usage of phytohormone amounts and ratios as biochemical markers for future hybrid canopy architecture could not be drawn.

Table 2. Phytohormone ratio in the leaves of hybrid families, according to their parental plant canopy architecture

\begin{tabular}{ccccccc}
\hline Crossing combination & IAA:Z & IAA:ABA & ABA:Z & GA $_{3}:$ ABA & GA $_{3}:$ IAA & GA $_{3}: Z$ \\
\hline \multirow{2}{*}{ Columnar $\times$ weeping } & $2.05 \mathrm{~b}$ & $4.49 \mathrm{~b}$ & $0.46 \mathrm{~b}$ & $112.6 \mathrm{~b}$ & $25.1 \mathrm{~b}$ & $51.6 \mathrm{~b}$ \\
& \pm 0.22 & \pm 0.56 & \pm 0.06 & \pm 9.99 & \pm 3.50 & \pm 5.64 \\
& $1.57 \mathrm{a}$ & $3.04 \mathrm{a}$ & $0.52 \mathrm{~b}$ & $44.5 \mathrm{a}$ & $14.6 \mathrm{a}$ & $23.0 \mathrm{a}$ \\
Columnar $\times$ standard & \pm 0.23 & \pm 0.51 & \pm 0.13 & \pm 4.59 & \pm 3.77 & \pm 4.31 \\
& $1.37 \mathrm{a}$ & $6.48 \mathrm{c}$ & $0.21 \mathrm{a}$ & $151.0 \mathrm{c}$ & $23.3 \mathrm{~b}$ & $32.0 \mathrm{a}$ \\
Weeping $\times$ standard & \pm 0.21 & \pm 0.58 & \pm 0.05 & \pm 14.26 & \pm 3.05 & \pm 5.49 \\
\hline
\end{tabular}

Explanations under Table 1

Phenotype of the hybrids was evaluated in the third year of growth when their canopy architecture was obvious and seedlings were divided into groups according to their canopy. Hybrids segregated into discrete classes according to their ideotype. Columnar apple tree form is controlled by single dominant $C o$ gene, hybrids in crosses of columnar and other ideotype apples segregate at 1:1 ratio (Tian et al., 2005). Hybrids in the crosses of columnar and other phenotype apples fitted 1:1 ratio, our data confirm this theory. Seedlings derived from crosses of weeping and standard ideotype apples segregated at 1:3 ratio, while columnar $\times$ weeping crossing combination segregated at 2:1:1 ratio, standard phenotype cultivars were found in this family together with seedlings that inherited their canopy from parental plants. Segregation shows that weeping apple tree ideotype is determined by recessive gene, similar results were obtained while studying Japanese chestnut and mulberry (Kotobuki et al., 2005; Yamanouchi et al., 2009), therefore we may state that weeping tree phenotype is determined by similar genetic factors in woody plants species. Phytohormone amount and ratio data from the first year of growth were calculated for each phenotype group (Tables 3-4).

Table 3. Phytohormone amount in the leaves of apple hybrid with a different canopy architecture

\begin{tabular}{ccccc}
\hline $\begin{array}{c}\text { Hybrid } \\
\text { phenotype }\end{array}$ & IAA & $\mathrm{Z}$ & $\mathrm{GA}_{3}$ & $\mathrm{ABA}$ \\
\hline Columnar & $6.01 \mathrm{c}$ & $3.73 \mathrm{ab}$ & $133.78 \mathrm{a}$ & $1.12 \mathrm{a}$ \\
& \pm 0.43 & \pm 0.43 & \pm 15.16 & \pm 0.21 \\
& $4.87 \mathrm{~b}$ & $3.90 \mathrm{~b}$ & $107.32 \mathrm{a}$ & $1.08 \mathrm{a}$ \\
Standard & \pm 0.46 & \pm 0.43 & \pm 8.61 & \pm 0.21 \\
& $3.24 \mathrm{a}$ & $2.75 \mathrm{a}$ & $107.41 \mathrm{a}$ & $1.19 \mathrm{a}$ \\
Weeping & \pm 0.10 & \pm 0.10 & \pm 2.61 & \pm 0.03 \\
\hline
\end{tabular}

Note. IAA - indole-3-acetic acid, $\mathrm{Z}$ - zeatin, $\mathrm{GA}_{3}$ - gibberellic acid 3, ABA - abscisic acid; means marked by the same letter do not differ significantly (significance at 0.05 level of probability according to Fisher's LSD test) (mean \pm SE, columnar $n=29$, standard $n=44$, weeping $n=17$ ). 
Differences in phytohormone amount between seedlings with all canopy ideotypes were significant for IAA, while $\mathrm{Z}$ distinguished between standard and weeping hybrids only. $\mathrm{GA}_{3}$ and $\mathrm{ABA}$ amounts were similar in all studied hybrids (Table 3). Watanabe et al. (2008) established that in columnar cultivars the IAA amount was higher in young apical shoots than in young lateral shoots; however, its amount was similar in these two organs in the standard cultivar. These data show that younger columnar cultivar tissues have more IAA and its amount is organ-specific, consequently it is possible to distinguish columnar genotypes according to IAA amount.

Table 4. Phytohormone ratio in the leaves of apple hybrid with a different canopy architecture

\begin{tabular}{ccccccc}
\hline Hybrid phenotype & IAA:Z & IAA:ABA & ABA:Z & GA $_{3}: A B A$ & GA $_{3}:$ IAA & GA $_{3}: Z$ \\
\hline \multirow{2}{*}{ Columnar } & $1.61 \mathrm{~b}$ & $5.36 \mathrm{~b}$ & $0.30 \mathrm{a}$ & $119.27 \mathrm{~b}$ & $22.26 \mathrm{a}$ & $35.91 \mathrm{ab}$ \\
& \pm 0.17 & \pm 0.47 & \pm 0.04 & \pm 7.60 & \pm 3.33 & \pm 5.26 \\
Standard & $1.22 \mathrm{a}$ & $4.51 \mathrm{~b}$ & $0.27 \mathrm{a}$ & $99.50 \mathrm{a}$ & $22.05 \mathrm{a}$ & $26.89 \mathrm{a}$ \\
& \pm 0.16 & \pm 0.33 & \pm 0.03 & \pm 7.46 & \pm 2.88 & \pm 3.21 \\
Weeping & $1.18 \mathrm{a}$ & $2.72 \mathrm{a}$ & $0.43 \mathrm{~b}$ & $90.01 \mathrm{a}$ & $33.15 \mathrm{~b}$ & $39.01 \mathrm{~b}$ \\
& \pm 0.08 & \pm 0.09 & \pm 0.01 & \pm 1.95 & \pm 0.64 & \pm 1.85 \\
\hline
\end{tabular}

Explanations under Table 3

IAA: $Z$ and $\mathrm{GA}_{3}: A B A$ ratios were the highest in the columnar apple hybrids, while these ratios were similar in standard and weeping hybrids (Table 4). Weeping apple hybrids were distinguished by lower IAA:ABA and higher $\mathrm{ABA}: \mathrm{Z}$ and $\mathrm{GA}_{3}$ :IAA ratios. However, these phytohormone ratios were different in parental weeping plants (Bendokas, Stanys, 2009), therefore they cannot be used as markers for weeping canopy architecture. IAA:ABA ratio in columnar hybrids was twice as high as in weeping ones. The highest amount of IAA was established in leaves of hybrids with columnar canopy (Table 3), and these hybrids also distinguished by significantly higher IAA:Z ratio (Table 4). The same trend was observed in parental plant study (Bendokas, Stanys, 2009). Also Tworkoski with co-authors (2006) established, that IAA:Z ratio is twice as high in columnar peach trees as in standard ones. These data show that the columnar tree ideotype is determined by high IAA concentration and high IAA:Z ratio, and this mechanism is common between plant genera. Our data show, that both juvenile and cropping columnar apple trees had higher IAA amount and IAA:Z ratio, consequently these phytohormones could be used as a biochemical marker for predicting future hybrid canopy architecture in the first year of growth. That enables identification and selection of columnar seedlings after growing for three months, thus shortening breeding.

Specific phytohormone balance for prediction of weeping apple ideotype was not identified. It is likely that development of weeping ideotype is determined genetically and is not regulated by phytohormones.

\section{Conclusion}

It was established that high amount of auxin (IAA) and higher auxin to cytokinin (IAA:Z) ratio are specific to the columnar apple tree ideotype and they can be used as biochemical markers in juvenile phase. High amount of IAA and higher IAA:Z ratio are similar in juvenile and cropping columnar apple trees, so these phytohormones are independent of tree development stage. It is possible to select columnar apple hybrids in the first year of growth, thus reducing duration of breeding process.

\section{Acknowledgements}

This work was supported by the long-term research program "Genetics and directed genotype development of agricultural and forestry plants" implemented by Lithuanian Research Centre for Agriculture and Forestry.

Received 12092013

Accepted 15012014

\section{References}

Aloni R., Aloni E., Langhans M., Ullrich C. 2006. Role of auxin in regulating Arabidopsis flower development. Planta, 223: 315-328 http://dx.doi.org/10.1007/s00425-005-0088-9

Bendokas V., Stanys V. 2009. Variation of hormones in apple trees with different canopy architecture. ZemdirbysteAgriculture, 96 (3): 76-82 (in Lithuanian)

Bendokas V., Gelvonauskiene D., Siksnianas T., Staniene G., Siksnianiene J. B., Gelvonauskis B., Stanys V. 2012. Morphological traits of phytomers and shoots in the first year of growth as markers for predicting apple tree canopy architecture. Plant Breeding, 131: 180-185 http://dx.doi.org/10.1111/j.1439-0523.2011.01902.x

Bernhard R. 1961. Mise a fleur et alternance chez les arbres fruitiers: congres pomologiques. INRA, Paris, France, p. 91-116 (in French)

Chan Z. L. 2012. Expression profiling of ABA pathway transcripts indicates crosstalk between abiotic and biotic stress responses in Arabidopsis. Genomics, 100: 110-115 http://dx.doi.org/10.1016/j.ygeno.2012.06.004

Cline M., Oh C. 2006. A reappraisal of the role of abscisic acid and its interaction with auxin in apical dominance. Annals of Botany, 98 (4): 891-897

http://dx.doi.org/10.1093/aob/mcl173 
Costes E., Lauri P. E., Regnard J. L. 2006. Analyzing fruit tree architecture: implications for tree management and fruit production. Horticultural Reviews, 32: 1-61

Esmon C. A., Pedmale U. V., Liscum E. 2005. Plant tropisms: providing the power of movement to a sessile organism. International Journal of Developmental Biology, 49: 665$674 \mathrm{http} / / / \mathrm{dx}$. doi.org/10.1387/ijdb.052028ce

Gray W. M. 2004. Hormonal regulation of plant growth and development. PLoS Biology, 2 (9): 1270-1274 http://dx.doi.org/10.1371/journal.pbio.0020311

Jackson J. E. 1980. Light interception and utilization by orchard systems. Horticultural Reviews, 2: 208-267

Kenis K., Keulemans J. 2007. Study of tree architecture of apple (Malus $\times$ domestica Borkh.) by QTL analysis of growth traits. Molecular Breeding, 19: 193-208 http://dx.doi.org/10.1007/s11032-006-9022-5

Kotobuki K., Sawamura Y., Saito T., Takada N. 2005. The mode of inheritance of weeping habit in Japanese chestnut, Castanea crenata. Acta Horticulturae, 693: 477-484

Lammerts van Bueren E. T., Backes G., de Vriend H., Østergard H. 2010. The role of molecular markers and marker assisted selection in breeding for organic agriculture. Euphytica, 175: 51-64 http://dx.doi.org/10.1007/s10681-010-0169-0

Lauri P. E., Terouanne E., Lespinasse J. M., Regnard J. L., Kelner J. J. 1995. Genotypic differences in the axillary bud growth and fruiting pattern of apple fruiting branches over several years - an approach to regulation of fruit bearing. Scientia Horticulturae, 64 (4): 265-281 http://dx.doi.org/10.1016/0304-4238(95)00836-5

Lauri P. E., Costes E., Regnard J. L., Brun L., Simon S., Monney P., Sinoquet H. 2008. Does knowledge on fruit tree architecture and its implications for orchard management improve horticultural sustainability? An overview of recent advances in the apple production: $1^{\text {st }}$ symposium on horticulture in Europe. Vienna, Austria, p. 122-123

Lespinasse Y. 1992. Breeding apple tree: aims and methods. Rousselle-Bourgeois F., Rousselle P. (eds). Proceedings of the joint conference of the EAPR Breeding and varietal assessment section and the EUCARPIA Potato section. Landerneau, France, p. 103-110

Lespinasse J. M., Delort J. F. 1986. Apple tree management in vertical axis: appraisal after ten years of experiments. Acta Horticulturae, 160: 139-155

Leyser O. 2009. The control of shoot branching: an example of plant information processing. Plant, Cell and Environment, 32: 694-703 http://dx.doi.org/10.1111/j.1365-3040.2009.01930.x

Ongaro V., Leyser O. 2007. Hormonal control of shoot branching. Journal of Experimental Botany, 59: 67-74 http://dx.doi.org/10.1093/jxb/erm134

Opik H., Rolfe S. 2005. Plant growth hormones. The physiology of flowering plants ( $4^{\text {th }}$ ed.)

Peer W. A., Blakeslee J. J., Yang H. B., Murphy A. S. 2011. Seven things we think we know about auxin transport. Molecular Plant, 4: 487-504 http://dx.doi.org/10.1093/mp/ssr034

Shimizu-Sato S., Tanaka M., Mori H. 2009. Auxin-cytokinin interactions in the control of shoot branching. Plant Molecular Biology, 69 (4): 429-435 http://dx.doi.org/10.1007/s11103-008-9416-3
Spoel S. H., Dong X. 2008. Making sense of hormone crosstalk during plant immune responses. Cell Host Microbe, 3: $348-351$ http://dx.doi.org/10.1016/j.chom.2008.05.009

Tarakanovas P., Raudonius S. 2003. Agronominių tyrimu duomenų statistinè analizè taikant kompiuterines programas ANOVA, STAT, SPLIT-PLOT iš paketo SELEKCIJA ir IRISTAT. Lithuanian University of Agriculture, $58 \mathrm{p}$. (in Lithuanian)

Tian Y. K., Wang C. H., Zhang J. S., James C., Dai H. Y. 2005. Mapping $C o$, a gene controlling the columnar phenotype of apple, with molecular markers. Euphytica, 145: 181-188 http://dx.doi.org/10.1007/s10681-005-1163-9

Tworkoski T., Miller S., Scorza R. 2006. Relationship of pruning and growth morphology with hormone ratios in shoots of pillar and standard peach trees. Journal of Plant Growth Regulation, 25: 145-155 http://dx.doi.org/10.1007/s00344-005-0123-x

Umehara M., Hanada A., Yoshida S., Akiyama K., Arite T., Takeda-Kamiya N., Magome H., Kamiya Y., Shirasu K., Yoneyama K., Kyozuka J., Yamaguchi S. 2008. Inhibition of shoot branching by new terpenoid plant hormones. Nature, 455: 195-200 http://dx.doi.org/10.1038/nature072732

Wang Y., Mopper S., Hasenstein K. H. 2003. Effects of salinity on endogenous ABA, IAA, JA and SA in Iris hexagona. Journal of Chemical Ecology, 27: 327-342 http://dx.doi.org/10.1023/A:1005632506230

Watanabe M., Bessho H., Suzuki A., Komori S. 2008. Seasonal changes of IAA and cytokinin in shoots of columnar type apple trees. Acta Horticulturae, 774: 75-80

Wickson M., Thimann K. V. 1958. The antagonism of auxin and kinetin in apical dominance. Physiologia Plantarum, 11 (1): $62-74$ http://dx.doi.org/10.1111/j.1399-3054.1958.tb08426.x

Wünsche J. N., Lakso A. N. 2000. The relationship between leaf area and light interception by spur and extension shoot leaves and apple orchard productivity. HortScience, 35 (7): 1202-1206

Yamanouchi H., Koyama A., Machii H., Takyu T., Muramatsu N. 2009. Inheritance of a weeping character and the low frequency of rooting from cuttings of the mulberry variety 'Shidareguwa'. Plant Breeding, 128 (3): 321-323 http://dx.doi.org/10.1111/j.1439-0523.2008.01587.x 
ISSN 1392-3196 / e-ISSN 2335-8947

Zemdirbyste-Agriculture, vol. 101, No. 3 (2014), p. 327-332

DOI 10.13080/z-a.2014.101.042

\title{
Naminès obels (Malus $\times$ domestica Borkh.) vainiko formos formavimosi prognozė: fitohormonų santykis hibriduose juvenaliniu raidos tarpsniu
}

\author{
V. Bendokas ${ }^{1}$, D. Gelvonauskienė $\dot{1}^{1}$, B. Gelvonauskis ${ }^{2}$, T. Šikšnianas ${ }^{1}$, V. Stanys ${ }^{1,3}$ \\ ${ }^{1}$ Lietuvos agrarinių ir miškų mokslų centro Sodininkystès ir daržininkystès institutas \\ ${ }^{2}$ Augalu genų bankas \\ ${ }^{3}$ Aleksandro Stulginskio universitetas
}

\section{Santrauka}

Naminès obels (Malus $\times$ domestica Borkh.) produktyvumas ir sodų ekonominė nauda priklauso nuo daugelio susijusių veiksnių. Vienas jų yra obels vainiko forma, kuri lemia derejimo tipą ir genejjimo poreikį. Dažniausiai vykdomi augimo reguliatorių, tręšimo, ūglių vystymosi ir genejjimo tyrimai, o skirtingos vainiko formos augalų fiziologiniai procesai mažiau tyrinèti. Fitohormonai labai svarbūs kontroliuojant augalo augimo ir vystymosi procesus. Nevienodos vainiko formos obelų ūgliuose fitohormonų kiekis skiriasi, tačiau duomenų apie fitohormonus ir jų santyki sodo augaluose juvenaliniu tarpsniu nėra. Tyrimo tikslas - nustatyti fitohormonus ir jų santyki, susijusius su obels vainiko forma juvenaliniu tarpsniu, ir numatyti jų panaudojimą prognozuojant būsimą obels hibridų vainiko formą pirmaisiais hibridų auginimo metais.

Nustatyta, kad koloninès vainiko formos obelims būdinga didelis kiekis auksino ir didelis auksino bei zeatino santykis, todèl šie fitohormonai gali būti naudojami kaip molekuliniai žymekliai juvenaliniu raidos tarpsniu. Šis fitohormonų kiekis ir santykis nepriklauso nuo koloninès vainiko formos obels vystymosi tarpsnio ir yra panašus juvenaliniu bei generatyviniu raidos tarpsniais. Pirmaisiais auginimo metais galima atrinkti koloninès vainiko formos hibridus ir taip sumažinti selekcijos kaštus.

Reikšminiai žodžiai: fitohormonų santykis, ideotipas, juvenalinis tarpsnis, Malus. 